\title{
Implementasi Algoritma K-Means Terhadap Pengelompokan Nilai Ujian Nasional Tingkat SMP di Provinsi Jawa Barat
}

\author{
${ }^{1}$ Tria Pratiwi Sutriyani, ${ }^{2}$ Amril Mutoi Siregar, ${ }^{3}$ Dwi Sulistya Kusumaningrum \\ ${ }^{1}$ if15.triasutriyani@mhs.ubpkarawang.ac.id, ${ }^{2}$ amrilmutoi@ubpkarawang.ac.id, \\ 3dwi.sulistya@ubpkarawang.ac.id \\ Universitas Buana Perjuangan Karawang \\ Karawang, Indonesia
}

\begin{abstract}
ABSTRAK
Peraturan Pemerintah Republik Indonesia Nomor 13 Tahun 2015 Pasal 66 menjelaskan bahwa Ujian Nasional (UN) sangatlah penting karena menjadi suatu pencapaian kompetensi lulusan secara nasional pada mata pelajaran tertentu pada Sekolah Dasar (SD), Sekolah Menengah Pertama (SMP) dan Sekolah Menengah Atas (SMA). Berdasarkan data yang ditemukan pada website Kementrian Pendidikan dan Kebudayaan yaitu nilai rata-rata UN SMP, SMA dan SMK data yang disajikan tidak berdasarkan peringkat atau kategori tertentu sehingga informasi yang didapatkan menjadi kurang jelas. Dari permasalahan tersebut dilakukan sebuah penelitian untuk menambang data menjadi informasi, pada penelitian ini data yang digunakan adalah nilai ratarata UN tingkat SMP di Provinsi Jawa Barat menggunakan teknik data mining. Penelitian dilakukan dengan cara perhitungan manual menggunakan Microsoft Excel Kemudian dievaluasi menggunakan tools Rapidminer 9.2.0. Penelitian ini menghasilkan Cluster Baik 10 Kabupaten/Kota, Cluster Cukup Baik 15 Kabupaten/Kota dan Cluster Kurang Baik 2 Kabupaten/Kota 2. Mata Pelajaran Matematika dan IPA saat ini tidak menentukan kategori, karena nilai yang didapat rata-rata lebih kecil dari Bahasa Inggris dan Bahasa Indonesia sehingga bagi Pemerintah Dinas Pendidikan untuk perlu meningkatkan lagi dalam proses pembelajaran di Provinsi Jawa Barat.
\end{abstract}

Kata kunci - Algoritma K-Means, Clustering, Data Mining, UN SMP.

\section{Pendahuluan}

Ujian Nasional atau UN merupakan salah satu penunjang keputusan untuk menyatakan lulus atau tidaknya siswa menurut Peraturan Pemerintah Republik Indonesia Nomor 13 Tahun 2015 Pasal 66 menyebutkan bahwa Penilaian hasil belajar sebagaimana dimaksud dalam Pasal 63 ayat (1) huruf c bertujuan untuk menilai pencapaian kompetensi lulusan secara nasional pada mata pelajaran tertentu dan dilakukan dalam bentuk UN. Selain itu, UN juga berpengaruh untuk melanjutkan jenjang pendidikan berikutnya, serta dapat meningkatkan mutu pendidikan sekolah tersebut sebagaimana tercantum pada Pasal 68 [1]. Kemudian ditemukan data nilai rata-rata UN Sekolah Menengah Pertama (SMP), Sekolah Menengah Atas (SMA) dan Sekolah Menengah Kejuruan (SMK) Tahun 2017 pada website Data Indonesia dalam Satu Portal [2] dengan rujukan dari website resmi Kementrian Pendidikan dan Kebudayaan (KEMDIKBUD) [3]. Data di publikasikan dalam bentuk format file Microsoft Excel (.xls) akan tetapi data yang disajikan masih secara acak tidak berdasarkan kategori atau peringkat tertentu sehingga informasi menjadi kurang jelas. Berdasarkan data yang diperoleh pada website KEMDIKBUD tersebut dilakukan penelitian menggunakan teknik data mining untuk menambang data menjadi informasi.

Terdapat banyak metode yang digunakan dalam data mining salah satunya adalah clustering atau pengelompokan merupakan metode yang digunakan untuk data yang tidak berlabel (unlabeled data) [4]. Salah satu algoritma dari metode clustering yaitu algoritma clustering $K$ Means. Berdasarkan X. Wu et al. [5] algoritma clustering K-Means merupakan sepuluh algoritma terbaik pada data mining yang digunakan untuk mengelompokan data-data ke dalam Cluster berdasarkan suatu kemiripan variabel atau atribut data. Penelitian algoritma K-Means telah dibuktikan berhasil untuk mengelompokan data oleh Yusuf dan Eka [6] tentang Penerapan Algoritma K-Means clustering pada Aplikasi menentukan Berat Badan Ideal dengan cara membandingkan titik pusat masing-masing data dengan titik pusat cluster yang telah ditetapkan. Selanjutnya pada penelitian Fitra, Abdul dan Mukis [7] tentang Pengelompokan Provinsi di Indonesia berdasarkan Karakteristik Kesejahteraan Rakyat menggunakan Metode K-Means Cluster yang membuktikan bahwa metode K-Means cluster dapat digunakan untuk pengelompokan Provinsi di Indnesia dibuat ke dalam tiga cluster. Hasil pengelompokan menunjukkan bahwa terdapat 6 provinsi pada cluster satu, 8 provinsi pada cluster dua, dan 19 provinsi pada cluster tiga. Kemudian, penelitian tentang Pengelompokan Mahasiswa berdasarkan 
nilai Ujian Nasional dan IPK menggunakan Metode K-Means dilakukan oleh Hartatik [8] membuktikan bahwa bahwa metode $K$-Means dapat digunakan untuk melakukan pengelompokan mahasiswa berdasarkan dua parameter yaitu IPK dan nilai UN mahasiswa tersebut ketika lulus SMU. Hasil cluster yang didapatkan adalah $\{0 ; 0\}$ untuk cluster yang pertama, $\{2,611 ; 6,38\}$ untuk cluster yang kedua dan $\{3,44 ; 7,095\}$ untuk cluster yang ketiga.

Pada penelitian ini data yang diteliti yaitu nilai rata-rata UN di Provinsi Jawa Barat pada Sekolah Menengah Pertama dengan menggunakan atribut Mata Pelajaran Bahasa Indonesia, Bahasa Inggris, Matematika dan Ilmu Pengetahuan Alam (IPA). Setelah dilakukan penelitian nilai rata-rata UN tingkat SMP di Provinsi Jawa Barat diharapkan mampu menambah dan memperjelas informasi dalam menunjang keputusan terutama pada Dinas Pendidikan Provinsi Jawa Barat berdasarkan nilai rata-rata UN.

Berdasarkan latar belakang masalah yang telah dipaparkan, maka penelitian ini menjabarkan permasalahan menjadi beberapa masalah yaitu bagaimana menerapkan Algoritma Clustering $K$ Means untuk mengelompokan Kabupaten dan Kota di Provinsi Jawa Barat berdasarkan Nilai UN tingkat Sekolah Menengah Pertama dan bagaimana hasil pengelompokan Kabupaten dan Kota di Provinsi Jawa Barat berdasarkan Nilai UN tingkat Sekolah Menengah Pertama dengan Algoritma Clustering K-Means.

\section{STUdi Literatur}

\section{A. Ujian Nasional}

Menurut Peraturan Pemerintah Republik Indonesia Nomor 13 Tahun 2015 Pasal 66 menyebutkan bahwa Penilaian hasil belajar sebagaimana dimaksud dalam Pasal 63 ayat (1) huruf c bertujuan untuk menilai pencapaian kompetensi lulusan secara nasional pada mata pelajaran tertentu dan dilakukan dalam bentuk UN. UN dilakukan secara obyektif, berkeadilan, dan akuntabel. UN diadakan paling sedikit 1 (satu) kali dalam 1 (satu) tahun pelajaran. Hasil UN digunakan sebagai salah satu dasar untuk pemetaan mutu program dan/atau satuan pendidikan, pertimbangan seleksi masuk jenjang pendidikan berikutnya pembinaan dan pemberian bantuan kepada satuan pendidikan dalam upayanya untuk meningkatkan mutu pendidikan Pasal 68 [1].

Peserta Didik pendidikan informal dapat memperoleh ijazah yang setara dengan ijazah dari pendidikan dasar dan menengah jalur formal atau nonformal setelah lulus uji kompetensi yang diselenggarakan oleh satuan pendidikan yang terakreditasi dan telah mengikuti UN bagi Peserta Didik sederajat SMP/MTs atau SMA/MA/SMK/MAK. Kriteria pencapaian Standar Kompetensi Lulusan, untuk jenjang SMP/SMPLB/MTs atau bentuk lain yang sederajat, SMA/SMALB/MA atau bentuk lain yang sederajat, dan SMK/MAK atau bentuk lain yang sederajat, Menurut Peraturan Pemerintah Republik Indonesia Nomor 13 Tahun 2015 [1].

\section{B. Data Mining}

Data mining muncul sekitar tahun 90-an juga sering dikenal sebagai Knowledge Discovery in Database $(K D D)$ [9]. Kehadirannya didasarkan dengan masalah membeludaknya data yang akhirakhir ini dimana banyak organisasi telah mengumpulkan data sekian tahun lamanya (data pembelian, data penjualan dan sebagainya). Data mining mengeksplorasi database untuk menemukan pola-pola yang tidak terlihat seperti mencari informasi untuk memprediksi penjualan yang mungkin saja terlupakan oleh pebisnis. Data mining adalah ekstraksi informasi atau pola yang penting atau menarik dari data yang ada di database yang besar [10]. Lebih lanjut, menurut Gartner Group data mining adalah suatu proses menemukan kolerasi, pola, dan tren baru yang bermakna dengan memilah-milah sejumlah besar data yang tersimpan dalam penyimpanan data, menggunakan teknologi pengenalan pola serta teknik statistik dan matematika.

\section{Pengelompokan Data Mining} [9]:

Data Mining dibagi menjadi beberapa kelompok berdasarkan tugas yang dapat dilakukan, yaitu

1. Deskripsi

Deskripsi memberikan penjelasan untuk suatu pola atau kecenderungan.

2. Estimasi

Estimasi hampir sama dengan klasifikasi, kecuali variabel target estimasi lebih ke arah numerik dari pada ke arah kategori. Model dibangun menggunakan record lengkap yang menyediakan nilai dari variabel target sebagai nilai prediksi.

3. Prediksi 
Prediksi hampir sama dengan klasifikasi dan estimasi, bahwa dalam prediksi nilai dari hasil akan ada di masa mendatang.

4. Klasifikasi

Dalam klasifikasi, terdapat target variabel kategori. Sebagai contoh, penggolongan pendapatan dapat dipisahkan dalam tiga kategori, yaitu pendapatan tinggi, pendapatan sedang, dan pendapatan rendah.

5. Pengelompokan (clustering)

Pengelompokan merupakan pengelompokan record, pengamatan, atau memperhatikan dan membentuk kelas objek-objek yang memiliki kemiripan. Cluster adalah kumpulan record yang memiliki kemiripan suatu dengan yang lainnya dan memiliki ketidakmiripan dengan record dalam kluster lain. Pengelompokan berbeda dengan klasifikasi yaitu tidak adanya variabel target dalam pengelompokan. Pengelompokan tidak mencoba untuk melakukan klasifikasi, mengestimasi, atau memprediksi nilai dari variabel target.

6. Asosiasi

Tugas asosiasi dalam data mining adalah menemukan atribut yang muncul dalam suatu waktu. Dalam dunia bisnis lebih umum disebut analisis keranjang belanja.

\section{Algoritma Clustering K-Means}

Fokus penelitian ini adalah Algoritma $K$-Means merupakan salah satu algoritma Clustering, tujuan algoritma ini yaitu untuk membagi data menjadi beberapa kelompok. Algoritma ini menerima masukan berupa data tanpa label kelas [4]. Algoritma standar K-Means adalah Algoritma Hartigan-Wong yang didefinisikan pada persamaan (1).

$$
\mathrm{W}(\mathrm{Ck}) \sum_{x i \in C k}(x i-\mu k)^{2}
$$

Dimana :

$\mathrm{Xi} \quad$ : $\quad$ sebuah data milik Cluster Ck

$\mu \mathrm{k} \quad$ : nilai rata-rata (mean) dari data-data pada Cluster $\mathrm{Ck}$

Langkah-langkah Algoritma Clustering K-Means dapat dijelaskan sebagai berikut :

1. Tentukan k buah Cluster.

2. Pilih sejumlah $\mathrm{k}$ buah objek secara acak yang akan dijadikan sebagai titik centroid Cluster.

3. Tentukan $\mathrm{k}$ buah centroid (titik tengah)

4. Kelompokkan objek ke centroid Cluster terdekat berdasarkan jarak objek ke centroid (Euclidean distance)

5. Hitung kembali semua nilai titik centroid

6. Ulangi langkah 3,4 dan 5 sampai nilai titik centroid tidak lagi berubah.

Selain Hartigan-Wong, terdapat rumus lainnya yaitu salah satunya adalah Euclidian Distance digunakan untuk menghitung titik centroid yang dijelaskan pada persamaan (2).

$$
\mathrm{d}(\mathrm{x}, \mathrm{y})=\sqrt{\sum_{i=1}^{n}(x i-y i)^{2}}
$$

Dimana :

$\mathrm{Xi} \quad$ : $\quad$ sebuah data milik Cluster Ck

Yi : Nilai objek

\section{E. Karakteristik K-Means}

Adapun Karakteristik Algoritma K-Means adalah sebagai berikut [4]:

\section{Clustering}

Clustering adalah proses pengelompokan objek-objek ke dalam beberapa kelompok yang berbeda, atau lebih tepatnya mempartisi dataset menjadi subsets.

2. Hierarchical Clustering

Merupakan jenis Clustering yang kompleks atau disebut juga multilevel hierarchy. Cluster yang lebih besar dikelompokan lagi menjadi dua atau lebih Cluster yang lebih kecil dan juga membentuk tree diagram yang disebut dendogram.

3. Density-based Clustering

Merupakan jenis Clustering yang berhubungan dengan kerapatan objek (densitas), dimana sekelompok objek yang lebih padat dipisahkan oleh sekelompok objek yang lebih renggang.

4. Model-based Clustering 
Merupakan jenis Clustering yang objeknya dibentuk melalui model, misal menggunakan model statistik standar.

5. Dataset untuk K-Means

Dataset merupakan sekumpulan data yang digunakan oleh Algoritma K-Means, dibagi menjadi dua jenis yaitu data berlabel (labeled data) dan data tanpa label (unlabeled data). Algoritma supervised learning memerlukan data berlabel. Sedangkan Unsupervised learing memerlukan data tanpa label. K-Means tergolong pada Unsupervised learing maka memerlukan data tanpa label. Selain itu bentuk data juga harus berupa bilangan atau numerik.

6. Nilai $\mathrm{K}$

Algoritma K-Means memerlukan nilai k, yang menyatakan jumlah Cluster, nilai K ini harus diinputkan diawal. Pilihan $\mathrm{K}$ yang tepat akan sangat mempengaruhi performa dari $K$ Means. Nilai k dapat ditebak atau menentukan nilai K sesuai kebutuhan.

7. Centroid

Setiap Cluster akan memiliki titik tengah (pusat) yang disebut centroid. Pertama centroid ditentukan secara acak, selanjutnya nilai centroid dijelaskan pada persamaan (3).

$$
\mathrm{c}=\sum_{i=1}^{n} \frac{x i}{n}
$$

Dimana :

$$
\begin{array}{lll}
\mathrm{C} & \text { : } & \text { Centroid pada cluster } \\
\mathrm{Xi} & : & \text { Titik/objek ke }-\mathrm{n}
\end{array}
$$

\section{F. Cross-Industry Standard Process for Data Mining (CRISP-DM)}

Cross-Industry Standard Process for Data Mining (CRISP-DM) yang dikembangkan tahun 1996 oleh analis dari beberapa industry seperti Daimler Chrysler, SPSS, dan NRC [11]. CRISP$D M$ menyediakan standar proses data mining sebagai strategi pemecah masalah secara umum dari bisnis dan unit penelitian. Dalam CRISP-DM sebuah proyek data mining memiliki siklus hidup yang terbagi dalam enam fase. Keseluruhan fase berurutan yang ada tersebut bersifat adaptif, fase berikutnya dalam urutan bergantung pada keluaran dari fase sebelumnya. Hubungan penting antarfase dihubungkan dengan tanda panah. Sebagai contoh jika fase berada dalam fase modelling. Berdasarkan pada perilaku dan karakteristik model, proses mungkin harus kembali kepada fase data preparation untuk perbaikan lebih lanjut terhadap data atau berpindah maju kepada fase evaluation.

\section{G. Rapidminer}

Rapidminer adalah perangkat lunak yang dapat diakses secara bebas (open source) untuk melakukan analisis data mining, text mining, dan analisis prediksi [10]. Perangkat lunak ini memiliki unggulan yakni berbasis open source di seluruh dunia yang termuka dan ternama serta lebih handal dalam menyediakan pembelajaran skema, model dan algoritma dari Weka dan $\mathrm{R}$ Script, selain data mining Rapidminer juga menyediakan fungsi seperti precessing data dan visualisasi, analisis prediktif dan pemodelan statistik, evaluasi dan penyebaran

\section{IMPLEMENTASI Algoritma K-MEANS TERHADAP PENGELOMPOKAN NiLAI UJIAN NASIONAL TINGKAT SMP DI PROVINSI JAWA BARAT}

\section{A. Tahap Pencarian Dataset}

Tahap pencarian dataset dilakukan dengan mencari data website di Data Indonesia dalam Satu Portal bersumber dari Kementrian Pendidikan dan Kebudayaan (KEMDIKBUD) [2].Data yang didapatkan berjumlah 2,196 data 14 atribut sehingga dilakukan penyeleksian data.

\section{B. Tahap Seleksi Data}

Dari data yang berjumlah 2,196 yang berisi 35 Provinsi dan 514 Kabupaten atau Kota lalu dari masing-masing data tersebut terdapat Sekolah Menengah Pertama, Sekolah menengah Atas Jurusan IPA dan IPS serta Sekolah Menengah Kejuruan dengan total keseluruhan yakni 2,196 data. Selain jumlah data tersebut terdapat juga 13 atribut yakni nilai rata-rata UN Mata Pelajaran Bahasa Indonesia, Bahasa Inggris, Matematika, IPA, Fisika, Kimia, Biologi, Ekonomi, Sosiologi, Kejuruan, Jumlah Peserta, Latitude, Longtitude. Berdasarkan data tersebut dilakukan penyeleksian data untuk memfokuskan penelitian dengan mengambil Data Sekolah Menengah Pertama di 
Provinsi Jawa Barat yang berjumlah 27 Kabupaten atau Kota dan Empat atribut yaitu data nilai rata-rata UN. Data yang telah diseleksi terdapat pada Tabel 1.

Tabel 1. Data yang akan diproses untuk pengelompokan

\begin{tabular}{|c|c|c|c|c|c|c|}
\hline No & Kode & Kabupaten/Kota & $\begin{array}{c}\text { Bahasa } \\
\text { Indonesia }\end{array}$ & $\begin{array}{l}\text { Bahasa } \\
\text { Inggris }\end{array}$ & MTK & IPA \\
\hline 1 & 1.0 & Kab. Bandung & 66.85 & 55.34 & 53.31 & 55.93 \\
\hline 2 & 2.0 & Kab. Bandung Barat & 66.45 & 54.61 & 53.71 & 55.90 \\
\hline 3 & 3.0 & Kab. Bekasi & 65.74 & 53.69 & 51.08 & 54.38 \\
\hline 4 & 4.0 & Kab. Bogor & 67.11 & 54.80 & 52.65 & 55.41 \\
\hline 5 & 5.0 & Kab. Ciamis & 70.54 & 56.72 & 55.89 & 57.59 \\
\hline 6 & 6.0 & Kab. Cianjur & 68.11 & 62.81 & 61.48 & 62.91 \\
\hline 7 & 7.0 & Kab. Cirebon & 66.21 & 51.96 & 50.67 & 53.70 \\
\hline 8 & 8.0 & Kab. Garut & 65.11 & 52.88 & 52.03 & 54.66 \\
\hline 9 & 9.0 & Kab. Indramayu & 64.02 & 51.29 & 50.09 & 53.46 \\
\hline 10 & 10.0 & Kab. Karawang & 65.26 & 56.84 & 56.21 & 58.23 \\
\hline 11 & 11.0 & Kab. Kuningan & 69.84 & 53.28 & 51.07 & 54.36 \\
\hline 12 & 12.0 & Kab. Majalengka & 68.28 & 53.83 & 52.00 & 54.34 \\
\hline 13 & 13.0 & Kab. Pangandaran & 66.41 & 51.65 & 50.17 & 53.10 \\
\hline 14 & 14.0 & Kab. Purwakarta & 65.67 & 51.52 & 49.97 & 53.22 \\
\hline 15 & 15.0 & Kab. Subang & 65.20 & 46.14 & 41.10 & 45.54 \\
\hline 16 & 16.0 & Kab. Sukabumi & 65.53 & 54.07 & 52.96 & 55.20 \\
\hline 17 & 17.0 & Kab. Sumedang & 67.82 & 48.90 & 42.22 & 46.53 \\
\hline 18 & 18.0 & Kab. Tasikmalaya & 67.59 & 54.48 & 53.04 & 55.68 \\
\hline 19 & 19.0 & Kota Bandung & 75.04 & 62.86 & 51.73 & 57.44 \\
\hline 20 & 20.0 & Kota Banjar & 69.60 & 52.70 & 50.04 & 53.68 \\
\hline 21 & 21.0 & Kota Bekasi & 73.02 & 61.23 & 55.01 & 57.82 \\
\hline 22 & 22.0 & Kota Bogor & 73.72 & 63.65 & 59.12 & 61.79 \\
\hline 23 & 23.0 & Kota Cimahi & 74.55 & 60.48 & 55.40 & 58.23 \\
\hline 24 & 24.0 & Kota Cirebon & 73.04 & 61.04 & 57.05 & 59.16 \\
\hline 25 & 25.0 & Kota Depok & 72.33 & 59.04 & 53.43 & 56.89 \\
\hline 26 & 26.0 & Kota Sukabumi & 72.09 & 59.06 & 54.64 & 57.63 \\
\hline 27 & 27.0 & Kota Tasikmalaya & 72.44 & 63.08 & 60.04 & 63.67 \\
\hline
\end{tabular}

\section{Tahap Implementasi Algoritma Clustering K-Means}

Setelah proses penyeleksian data lalu tahap selanjutnya yaitu pengolahan dataset menggunakan Algoritma Clustering K-Means dengan menentukan Cluster. Saat ini belum ada indikator resmi untuk menentukan kategori sehingga pada penelitian ini digunakan tiga Cluster yaitu Baik, Cukup Baik dan Kurang Baik.

\section{Hasil Pengelompokan}

Hasil pengelompokan ini nantinya menghasilkan Kabupaten atau Kota mana saja yang merupakan Cluster Baik, Cukup Baik dan Kurang Baik berdasarkan nilai rata-rata UN

\section{E. Tahap Evaluasi}

Setelah mengetahui hasil pengelompokan nilai rata-rata UN tingkat SMP di Provinsi Jawa Barat secara perhitungan manual mengunakan Microsoft Office dengan Algoritma K-Means, selanjutnya dilakukan evaluasi menggunakan tools Rapidminer untuk membandingkan hasil keduanya.

\section{Hasil dan Pembahasan}

Hasil Perhitungan manual menggunakan Microsoft Excel 2013 dilakukan sebanyak 8 iterasi sampai titik centroid tidak lagi berubah dengan menghitung jarak menggunakan persamaan (2). Setelah menghitung jarak kemudian dilakukan perhitungan titik centroid baru dengan menggunakan persamaan (3). Sehingga hasil iterasi terakhir didapat pada Tabel 2 dimana angka yang bercetak tebal (bold) berada pada cluster $\mathrm{C} 1, \mathrm{C} 2$ atau $\mathrm{C} 3$.

Tabel 2. Hasil Pengelompokan secara Perhitungan Manual

\begin{tabular}{|l|r|r|r|r|r|r|r|}
\hline \multicolumn{1}{|c|}{ Kabupaten/Kota } & $\begin{array}{c}\text { Bahasa } \\
\text { Indonesia }\end{array}$ & $\begin{array}{c}\text { Bahasa } \\
\text { Inggris }\end{array}$ & \multicolumn{1}{c|}{ MTK } & IPA & C1 & C2 & C3 \\
\hline Kab. Bandung & 66.85 & 55.34 & 53.31 & 55.93 & 17.17270 & 9.20066 & $\mathbf{2 . 5 7 0 6 6}$ \\
\hline Kab. Bandung Barat & 66.45 & 54.61 & 53.71 & 55.90 & 17.11118 & 9.79915 & $\mathbf{2 . 3 8 4 2 8}$ \\
\hline Kab. Bekasi & 65.74 & 53.69 & 51.08 & 54.38 & 14.03699 & 12.30210 & $\mathbf{1 . 3 0 7 4 1}$ \\
\hline Kab. Bogor & 67.11 & 54.80 & 52.65 & 55.41 & 16.18731 & 9.82164 & $\mathbf{1 . 6 6 7 4 4}$ \\
\hline Kab. Ciamis & 70.54 & 56.72 & 55.89 & 57.59 & 20.90196 & $\mathbf{5 . 0 2 9 4 4}$ & 7.00534 \\
\hline
\end{tabular}




\begin{tabular}{|l|r|r|r|r|r|r|r|}
\hline \multicolumn{1}{|c|}{ Kabupaten/Kota } & $\begin{array}{c}\text { Bahasa } \\
\text { Indonesia }\end{array}$ & $\begin{array}{c}\text { Bahasa } \\
\text { Inggris }\end{array}$ & \multicolumn{1}{l|}{ MTK } & \multicolumn{1}{c|}{ IPA } & C1 & C2 & C3 \\
\hline Kab. Cianjur & 68.11 & 62.81 & 61.48 & 62.91 & 30.23148 & $\mathbf{7 . 8 3 6 6 1}$ & 15.68446 \\
\hline Kab. Cirebon & 66.21 & 51.96 & 50.67 & 53.70 & 12.63867 & 13.60805 & $\mathbf{2 . 3 1 3 0 6}$ \\
\hline Kab. Garut & 65.11 & 52.88 & 52.03 & 54.66 & 14.58140 & 12.68404 & $\mathbf{1 . 6 7 1 6 1}$ \\
\hline Kab. Indramayu & 64.02 & 51.29 & 50.09 & 53.46 & 12.10820 & 15.48360 & $\mathbf{4 . 1 1 8 9 2}$ \\
\hline Kab. Karawang & 65.26 & 56.84 & 56.21 & 58.23 & 21.18597 & 8.40988 & $\mathbf{6 . 5 7 8 6 1}$ \\
\hline Kab. Kuningan & 69.84 & 53.28 & 51.07 & 54.36 & 14.21690 & 10.92162 & $\mathbf{3 . 3 4 2 1 2}$ \\
\hline Kab. Majalengka & 68.28 & 53.83 & 52.00 & 54.34 & 14.79316 & 10.62918 & $\mathbf{1 . 7 1 3 8 4}$ \\
\hline Kab. Pangandaran & 66.41 & 51.65 & 50.17 & 53.10 & 11.80683 & 14.19371 & $\mathbf{3 . 0 6 9 0 1}$ \\
\hline Kab. Purwakarta & 65.67 & 51.52 & 49.97 & 53.22 & 11.72117 & 14.64577 & $\mathbf{3 . 3 4 4 1 0}$ \\
\hline Kab. Subang & 65.20 & 46.14 & 41.10 & 45.54 & $\mathbf{2 . 0 4 4 2 9}$ & 26.40054 & 16.08958 \\
\hline Kab. Sukabumi & 65.53 & 54.07 & 52.96 & 55.20 & 15.98594 & 11.18049 & $\mathbf{1 . 6 7 0 7 3}$ \\
\hline Kab. Sumedang & 67.82 & 48.90 & 42.22 & 46.53 & $\mathbf{2 . 0 4 4 2 9}$ & 23.06534 & 13.59152 \\
\hline Kab. Tasikmalaya & 67.59 & 54.48 & 53.04 & 55.68 & 16.49662 & 9.52939 & $\mathbf{1 . 9 7 1 5 6}$ \\
\hline Kota Bandung & 75.04 & 62.86 & 51.73 & 57.44 & 23.22833 & $\mathbf{5 . 9 2 4 9 3}$ & 12.83824 \\
\hline Kota Banjar & 69.60 & 52.70 & 50.04 & 53.68 & 12.84721 & 12.21042 & $\mathbf{3 . 7 6 1 8 3}$ \\
\hline Kota Bekasi & 73.02 & 61.23 & 55.01 & 57.82 & 23.39771 & $\mathbf{2 . 1 0 7 2 5}$ & 10.90119 \\
\hline Kota Bogor & 73.72 & 63.65 & 59.12 & 61.79 & 29.41484 & $\mathbf{4 . 7 1 2 2 0}$ & 15.92790 \\
\hline Kota Cimahi & 74.55 & 60.48 & 55.40 & 58.23 & 23.87695 & $\mathbf{2 . 5 7 8 8 5}$ & 11.61612 \\
\hline Kota Cirebon & 73.04 & 61.04 & 57.05 & 59.16 & 25.19026 & $\mathbf{0 . 8 8 3 2 9}$ & 11.95570 \\
\hline Kota Depok & 72.33 & 59.04 & 53.43 & 56.89 & 20.56567 & $\mathbf{4 . 2 9 2 1 3}$ & 8.33727 \\
\hline Kota Sukabumi & 72.09 & 59.06 & 54.64 & 57.63 & 21.61556 & $\mathbf{3 . 1 2 5 2 2}$ & 8.70979 \\
\hline Kota Tasikmalaya & 72.44 & 63.08 & 60.04 & 63.67 & 30.43183 & $\mathbf{6 . 0 6 0 3 3}$ & 16.43428 \\
\hline
\end{tabular}

Setelah mengetahui hasil pengelompokan pada Tabel 2, selanjutnya menentukan kategori Baik, Cukup Baik dan Kurang Baik dengan mengurutkan jumlah nilai dari terkecil, sedang dan tertinggi. Sehingga didapatkan hasil akhir pengelompokan secara manual yang terdapat pada Tabel 3.

Tabel 3. Hasil Pengelompokan Manual

\begin{tabular}{|c|l|c|}
\hline Cluster & \multicolumn{1}{|c|}{ Kabupaten/Kota } & Jumlah \\
\hline Baik & $\begin{array}{l}\text { Kabupaten Ciamis, Kabupaten Cianjur, Kota Bandung, Kota Bekasi, Kota Bogor, Kota } \\
\text { Cimahi, Kota Cirebon, Kota Depok, Kota Sukabumi, Kota Tasikmalaya }\end{array}$ & 10 \\
\hline Cukup Baik & $\begin{array}{l}\text { Kabupaten Bandung, Kabupaten Bandung Barat, Kabupaten Bekasi, Kabupaten Bogor, } \\
\text { Kabupaten Cirebon, Kabupaten garut, Kabupaten Indramayu, Kabupaten Karawang, } \\
\text { Kabupaten Kuningan, Kabupaten Majalengka, Kabupaten Pangandaran, Kabupaten } \\
\text { Purwakarta, Kabupaten Sukabumi, Kabupaten Tasikmalaya, Kota Banjar }\end{array}$ & 15 \\
\hline Kurang Baik & Kabupaten Subang, Kabupaten Sumedang & 2 \\
\hline
\end{tabular}

Berdasarkan hasil perhitungan secara manual menggunakan Microsoft Excel pada Tabel 2 dan otomatis menggunakan tools Rapidminer pada Tabel 4. Kelompok yang dihasilkan sama, yaitu Cluster Baik 10 Kabupaten/Kota, Cluster Cukup Baik 15 Kabupaten/Kota dan Kurang Baik 2 Kabupaten/Kota.

Tabel 4. Hasil Pengelompokan tools Rapidminer

\begin{tabular}{|c|l|c|}
\hline Cluster & \multicolumn{1}{|c|}{ Kabupaten/Kota } & Jumlah \\
\hline Baik & $5.0,6.0,19.0,21.0,22.0,23.0,24.0,25.0,26.0,27.0$ & 10 \\
\hline Cukup Baik & $1.0,2.0,3.0,4.0,7.0,8.0,9.0,10.0,11.0,12.0,13.0,14.0,16.0,18.0,20.0$ & 15 \\
\hline Kurang Baik & $15.0,17.0$ & 2 \\
\hline
\end{tabular}

Hasil pengelompokan Kabupaten dan Kota di Provinsi Jawa Barat berdasarkan nilai UN tingkat SMP dibagi menjadi tiga kelompok yaitu Baik sebanyak 15 Kabupaten/Kota, Cukup Baik sebanyak 10 Kabupaten/Kota dan Kurang Baik sebanyak 2 Kabupaten. Hasil tersebut didapat dari perhitungan manual menggunakan Microsoft Excel sebanyak 8 iterasi sampai titik centroid yang didapat tidak lagi berubah. Hasil yang didapat pada iterasi ke-8 titik centroid yang didapat sama maka proses iterasi dihentikan sampai dengan iterasi 8 walaupun ada beberapa jumlah anggota pada cluster yang sama di iterasi tiga dan lima, empat dan enam tidak berpengaruh karena titik centroid berbeda. Kabupaten atau Kota yang termasuk dalam kategori Baik memiliki jumlah nilai UN 233.45 - 263.84, kategori Cukup Baik 218.38 - 241.12 dan Kurang Baik 197.98 - 205.47. Penentuan kategori ditentukan oleh mata pelajaran Bahasa Inggris dan bahasa Indonesia karena dilihat dari rata-rata nilai UN mata pelajaran Bahasa Indonesia dan Bahasa Inggris cenderung lebih besar dari Matematika dan IPA sehingga Bahasa Indonesia dan bahasa Inggris sebagai penentu 
dalam pengelompokan Kabupaten/Kota di Provinsi Jawa Barat berdasarkan nilai Ujian Nasioanal tingkat SMP ini.

\section{KESIMPULAN DAN SARAN}

Berdasarkan hasil penelitian yang telah dilakukan, maka kesimpulan dari penelitian ini adalah :

1. Algoritma clustering K-Means dapat digunakan untuk pengelompokan nilai UN tingkat SMP di Provinsi Jawa Barat dengan cara melakukan proses awal menyeleksi data, selanjutnya menerapkan algoritma K-Means yang diawali dengan menentukan nilai k atau jumlah cluster lalu menghitung jarak objek ke titik centroid kemudian hasil perhitungan jarak tersebut dibandingkan untuk melihat jarak terdekat setelah itu menghitung kembali titik centroid baru dan dilakukan secara berulang hingga titik centroid lama dan titik centroid baru tidak lagi berubah.

2. Hasil Pengelompokan menggunakan Algoritma clustering $K$-Means secara manual dan menggunakan tools menghasilkan kategori baik terdiri dari Kabupaten Ciamis, Kabupaten Cianjur, Kota Bandung, Kota Bekasi, Kota Bogor, Kota Cimahi, Kota Cirebon, Kota Depok, Kota Sukabumi, Kota Tasikmalaya. Kategori cukup baik terdiri dari Kabupaten Bandung, Kabupaten Bandung Barat, Kabupaten Bekasi, Kabupaten Bogor, Kabupaten Cirebon, Kabupaten Garut, Kabupaten Indramayu, Kabupaten Karawang, Kabupaten Kuningan, Kabupaten Majalengka, Kabupaten Pangandaran, Kabupaten Purwakarta, Kabupaten Sukabumi, Kabupaten Tasikmalaya, Kota Banjar dan kategori kurang baik terdiri dari Kabupaten Subang, Kabupaten Sumedang. Sehingga jika dikelompokan menurut jumlah nilai UN jika Jumlah nilai UN 233.45 - 263.84 termasuk kategori baik, 218.38 - 214.12 termasuk kategori cukup baik dan 197.98 - 205.47 termasuk kategori kurang baik.

Hasil penelitian untuk meningkatkan Kategori Kabupaten/Kota di Provinsi Jawa Barat, nilai yang harus ditingkatkan adalah Bahasa Inggris dan Bahasa Indonesia, karena kedua mata pelajaran tersebut merupakan penentu untuk mendapatkan kategori Baik, Cukup Baik atau Kurang Baik sedangkan Matematika dan IPA tidak menjadi penentu karena kedua mata perlajaran tersebut hampir sama rata. Kemudian untuk penelitian selanjutnya diharapkan dapat menggunakan lebih dari tiga cluster dan dalam pemilihan titik centroid yang berbeda serta menggunakan algoritma clustering lainnya.

\section{Daftar Pustaka}

[1] "Peraturan Pemerintah Republik Indonesia Nomor 13 Tahun 2015,” no. 2, 2015.

[2] "Data Indonesia dalam Satu Portal," 2017. .

[3] "Jendela Pendidikan dan Kebudayaan.".

[4] R. Primartha, Belajar Mechine Learning. Bandung: Informatika Bandung, 2018

[5] X. Wu et al., Top 10 algorithms in data mining. Verlag London Limiter, 2008.

[6] Y. R. Nasution et al., "Penerapan Algoritma K-Means Clustering pada Aplikasi menentukan Berat Badan Ideal," vol. 6341, no. April, pp. 77-81, 2018.

[7] J. Gaussian, "Pengelompokan Provinsi di Indonesia berdasarkan Karakteristik Kesejahteraan Rakyat menggunakan Metode K-Means Cluster,”vol. 4, no. 2006, pp. 875-884, 2015.

[8] Hartatik, "Pengelompokan Mahasiswa Berdasarkan Nilai Ujian Nasional dan IPK menggunakan Metode KMeans," pp. 35-40, 2014.

[9] D. Larose, Discovering Knowledge in Data. Canada: A John Wiley \& Sons, Inc, 2005.

[10] A. Siregar and A. Paspabhuana, Pengolahan Data menjadi Informasi dengan Rapidminer. Surakarta, 2017.

[11] Kusrini and E. Luthfi, Algoritma data Mining. Yogyakarta: ANDI, 2009. 